\title{
Slaughter and carcass characteristics, chemical composition and physical properties of longissimus lumborum muscle of heifers as related to marbling class
}

\author{
A. Oler ${ }^{1}$, B. Głowińska ${ }^{2}$, and K. Młynek ${ }^{3}$ \\ ${ }^{1}$ Department of Cattle Breeding, University of Technology and Life Sciences, Bydgoszcz, Poland \\ ${ }^{2}$ Department of Animal Physiology, University of Technology and Life Sciences, Bydgoszcz, Poland \\ ${ }^{3}$ Department of Cattle Breeding and Milk Evaluation, Siedlce University of Natural Sciences and Humanities, \\ Siedlce, Poland
}

Correspondence to: B. Głowińska (bglow@utp.edu.pl)

Received: 6 November 2014 - Accepted: 10 March 2015 - Published: 2 April 2015

\begin{abstract}
The experiment involved 68 heifers obtained from Polish Black-and-White Lowland dams (with no more than $50 \%$ Holstein Friesian blood) sired by Limousin bulls. The study was arranged to determine the slaughter and carcass traits, chemical composition and physical properties of musculus longissimus lumborum (MLL) as related to the level of marbling, and to examine the correlation between some of the traits mentioned above and the culinary characteristics of meat. The results of the study show that marbling significantly affected the dressing percentage and carcass traits such as subcutaneous fat content, fat of valuable cuts and MLL area. Most of the physico-chemical properties of tested muscles, with the exception of total protein and total collagen content, were related to the level of marbling. Based on the results obtained, it appears that age at slaughter and carcass weight turned out to be poor predictors of colour lightness within all marbling classes. The same conclusion applies to the amount of total collagen in large and strong marbled muscles for shear force value. In turn, soluble collagen content for shear force could be a quite good forecaster of meat tenderness but not in highly marbled muscles. Of all tested slaughter and carcass traits, only MLL fat content seems to be appropriate to assess both: the tenderness and lightness of meat.
\end{abstract}

\section{Introduction}

The need for a continuous improvement of slaughter and carcass traits, as well as the quality characteristics of meat demanded by consumers, are the principal objectives of beef production investigations. Beside the meat acidity and water holding capacity, the beef colour and tenderness make up the basic quality characteristics essential for both consumers and the processing industry (Wegner et al., 2000; Vestergaard et al., 2000).

Beef appearance is an essential factor at the moment of purchase and its colour and marbling are properties which consumers take into account first (Platter et al., 2005). In turn meat tenderness it is the trait determining beef quality (Warner et al., 2010). Total amount and chemical composition of collagen in the muscle as well as quantity of connec- tive tissue is some of the factors directly affecting beef tenderness, while marbling is a factor indirectly affecting meat toughness (Wulf et al., 1996; Nishimura et al., 1999; Ueda et al., 2007). With respect to meat colour, some authors observed a significant relationship between marbling and meat lightness (Fiems et al., 2000), whereas others (Kim and Lee, 2003) reported that marbling did not affect the beef colour.

Marbling appears in raw meat as white spots or strips of fat, which describes the distribution of intramuscular fat (IMF). In turn, IMF is the chemically estimated fat content of meat; the terms marbling and IMF are commonly used alternatively. This characteristic presents considerable variability both between (Chambaz et al., 2001; Šurbt et al., 2006) and within breed populations (Węglarz, 2010a) and among muscle types depending on their anatomy and the physiological role played (Rhee et al., 2004, Searls et al., 2005). 
The selection of leaner beef carcasses leads to lower intramuscular fat, while IMF plays an important role in culinary and eating attributes, affecting, e.g. meat tenderness (Nishimura et al., 1999), meat colour (Fiems et al., 2000), beef juiciness (Okumura et al., 2007) and meat flavour, and a small amount of fat (about 2.0-2.5\%) is necessary for good culinary quality (Thompson, 2004).

The assumption of the present study is that differences in carcass characteristics and physico-chemical traits of heifer longissimus lumborum muscle are connected with intramuscular fat content, and that the relationship between tested parameters depends on the level of marbling. Therefore, the experiment was arranged to determine the slaughter and carcass traits, chemical composition and physical properties of musculus longissimus lumborum (MLL) as related to the amount of intramuscular fat, and to examine the correlation between some of the above traits and culinary characteristics of meat.

\section{Material and methods}

The study was conducted under a research protocol approved by the III Local Ethical Committee in Warsaw (No. 62/2009 from 25 September 2009).

\subsection{Animals}

The experiment involved 68 heifers obtained from Polish Black-and-White Lowland dams (with no more than $50 \%$ Holstein Friesian blood) sired by Limousin bulls. The animals originated from three farms with similar feeding and housing conditions. In the autumn-winter period, all the heifers were fed hay (ad libitum), corn silage and compound cereal meal, and in summer they received green fodder ( $\mathrm{ad} \mathrm{li-}$ bitum), crushed cereal grain and a small addition of hay. The diets were formulated according to the maintenance requirement of animals specified by French National Institute for Agricultural Research (INRA) feeding standards with the use of INRAtion Software for Ruminant Diet Calculation, version 2.03 (DJ Group, Krakow, Poland), drawing on the earlier chemical analysis of feeds and calculating their nutritional value. The time of cattle transport to the slaughterhouse was approximately $3 \mathrm{~h}$. After a $24 \mathrm{~h}$ rest, heifers were slaughtered and after post-slaughter processing carcasses were cooled at $4{ }^{\circ} \mathrm{C}$.

\subsection{Sample collection}

$24 \mathrm{~h}$ after cooling the musculus longissimus lumborum (MLL) area and subcutaneous fat thickness were measured between the last thoracic vertebra and the first lumbar vertebra. The samples of MLL were taken from the central part of the muscle and the evaluation of marbling was performed on the same samples by three independent persons, based on a five-point marbling scale ( 1 point $=$ imperceptible to 5 points $=$ strong). Degree of marbling was presented in tables as marbling class (class II and III with 16 individuals, class IV with 19 and V with 17 individuals). Other meat samples were packed into separate plastic bags, which were cooled at $4^{\circ}$ for the next $24 \mathrm{~h}$. Within $48 \mathrm{~h}$ post-mortem, the chemical and physical properties of MLL were determined.

\subsection{Chemical and physical analysis}

Chemical analysis of the meat (dry matter, total protein and fat content) was performed according to the standard procedures of the Association of Official Analytical Chemists (AOAC, 1995). Total collagen content was estimated in raw meat, whereas samples designed for insoluble collagen analysis were thermally treated until the internal temperature of $+75^{\circ} \mathrm{C}$ was reached. Collagen content was determined in fat-free dry matter, so all the meat samples were degreased by homogenization with frozen acetone $(1: 20)$, and then the hydroxyproline content was determined according to the standard procedure of the International Organization for Standardization (ISO, 1994). The absorbance was read using VARIAN CARY 300 bio spectrophotometer (Varian, Inc., Palo Alto, CA, USA). Total collagen was calculated as hydroxyproline $\times 7.25$ and expressed as milligrams of collagen per gram of fat-free dry matter. The amount of soluble collagen was calculated from the difference between total and insoluble collagen content and was expressed as the percentage of total collagen. The meat tenderness was measured based on shear force with the use of a Warner-Bratzler shear blade. Muscle samples (with a cross-section area of $1 \mathrm{~cm}^{2}$ perpendicular to the muscle fibres) was analysed after heating at $75^{\circ}$ and $30 \mathrm{~min}$. The mean value of 3 replicate analyses of the same sample was expressed in $\mathrm{N} \mathrm{cm}^{-2}$. The meat lightness (colour $L$ ) was estimated using Minolta Chroma Meter CR-310-HUNTER LAB system (Minolta Camera Co., Ltd., Osaka, Japan) with the $1.0 \mathrm{~cm}$ thick slices.

\subsection{Statistical analysis}

Data were statistically analysed using SAS, version 9.3 (SAS Institute, Inc., Cary, NC, USA). All the results are given in tables as least square means (LSM) with the standard error of the mean (SE) and were subjected to one-way analysis of variance to evaluate the influence of marbling on tested parameters ( $P$ value). Differences between means were tested by Tukey's method and the probability of $P<0.05$ was accepted as significant. Additionally, within marbling classes, Pearson's correlation of shear force with some of the meat characteristics, and correlation of colour $L$ parameter with some slaughter and carcass traits were estimated using the CORR procedure of SAS.

\section{Results}

Data presented in Table 1 show that age at slaughter and carcass weight reached almost the same values in all mar- 
Table 1. Slaughter traits and carcass analysis.

\begin{tabular}{|c|c|c|c|c|c|c|}
\hline & \multicolumn{4}{|c|}{ Marbling class } & \multirow[b]{3}{*}{ SE } & \multirow[b]{3}{*}{$P$ value } \\
\hline & $\begin{array}{l}\text { II } \\
(n=16)\end{array}$ & $\begin{array}{l}\text { III } \\
(n=16)\end{array}$ & $\begin{array}{l}\text { IV } \\
(n=19)\end{array}$ & $\begin{array}{l}\mathrm{V} \\
(n=17)\end{array}$ & & \\
\hline & LSM & LSM & LSM & LSM & & \\
\hline Age at slaughter (days) & 551 & 546 & 555 & 562 & 3.54 & 0.256 \\
\hline Carcass weight $(\mathrm{kg})$ & 223 & 226 & 223 & 218 & 1.10 & 0.726 \\
\hline Dressing percentage & $57.9^{\mathrm{a}}$ & $56.1^{\mathrm{b}}$ & $56.1^{\mathrm{b}}$ & $53.8^{\mathrm{c}}$ & 0.25 & 0.037 \\
\hline Subcutaneous fat $(\mathrm{cm})$ & $0.77^{\mathrm{a}}$ & $0.85^{\mathrm{a}}$ & $0.92^{\mathrm{b}}$ & $1.25^{\mathrm{c}}$ & 0.03 & 0.019 \\
\hline Fat of valuable cuts (\%) & $4.6^{\mathrm{a}}$ & $6.3^{b}$ & $6.3^{b}$ & $7.5^{\mathrm{c}}$ & 0.14 & 0.004 \\
\hline MLL area $\left(\mathrm{cm}^{2}\right)$ & $61.7^{\mathrm{a}}$ & $64.2^{\mathrm{b}}$ & $65.0^{\mathrm{b}}$ & $65.7^{\mathrm{b}}$ & 0.27 & 0.046 \\
\hline
\end{tabular}

Table 2. Chemical composition and physical properties of longissimus lumborum muscle.

\begin{tabular}{|c|c|c|c|c|c|c|}
\hline & \multicolumn{4}{|c|}{ Marbling class } & \multirow[b]{2}{*}{ SE } & \multirow[b]{2}{*}{$P$ value } \\
\hline & $\begin{array}{l}\text { II } \\
(n=16) \\
\text { LSM }\end{array}$ & $\begin{array}{l}\text { III } \\
(n=16) \\
\text { LSM }\end{array}$ & $\begin{array}{l}\text { IV } \\
(n=19) \\
\text { LSM }\end{array}$ & $\begin{array}{l}\mathrm{V} \\
(n=17) \\
\mathrm{LSM}\end{array}$ & & \\
\hline Dry matter $(\%)$ & $22.3^{\mathrm{a}}$ & $22.4^{\mathrm{a}}$ & $23.4^{\mathrm{b}}$ & $24.4^{\mathrm{b}}$ & 0.23 & 0.035 \\
\hline Total protein $(\%)$ & 20.7 & 20.4 & 20.1 & 20.0 & 0.17 & 0.441 \\
\hline MLL fat (\%) & $2.4^{\mathrm{a}}$ & $3.4^{\mathrm{b}}$ & $3.5^{\mathrm{b}}$ & $4.5^{\mathrm{c}}$ & 0.11 & 0.004 \\
\hline Total collagen & 4.0 & 3.9 & 3.5 & 3.6 & 0.10 & 0.272 \\
\hline Soluble collagen ( $\%$ of total collagen) & $19.1^{\mathrm{a}}$ & $18.0^{\mathrm{b}}$ & $16.5^{\mathrm{c}}$ & $16.4^{\mathrm{c}}$ & 0.28 & 0.028 \\
\hline Shear force $\left(\mathrm{N} \mathrm{cm}^{-2}\right)$ & $50.1^{\mathrm{a}}$ & $50.8^{\mathrm{a}}$ & $46.5^{\mathrm{b}}$ & $42.6^{\mathrm{c}}$ & 0.63 & 0.003 \\
\hline Colour L & $33.9^{\mathrm{a}}$ & $30.1^{\mathrm{b}}$ & $28.9^{\mathrm{c}}$ & $27.8^{\mathrm{c}}$ & 0.51 & 0.007 \\
\hline
\end{tabular}

bling classes of longissimus lumborum muscle. The dressing percentage was highest $(P<0.05)$ in small marbled muscle (class II) and least significant in V marbling class. The results indicated that subcutaneous fat thickness significantly increased with increasing marbling class and the same trend concerned the percentage of fat of valuable cuts. Also the value of MLL area was higher with increasing marbling class and the result for class II was significantly lower compared with remaining classes.

The MLL of class II and III contained less dry matter $(P<0.05)$ relative to IV and $\mathrm{V}$ classes (Table 2). Total protein and total collagen content in the muscle was not influenced by marbling class. The most significant level of MLL fat was found in marbling class V and the lowest in II. No differences in this parameter occurred between medium (III) and large (IV) classes. The results showed that soluble collagen content and meat lightness decreased with rising marbling class, and only between classes IV and V were there no sig- nificant differences. In turn, in $\mathrm{V}$ class of marbling the value of shear force was lowest $(P<0.05)$ compared with remaining classes.

The correlation between shear force and the content of fat in MLL was negative in all marbling classes and the highest level of correlation (-0.897) was found in class III (Table 3). The results showed that the values in each marbling class are significant. Also, the highest but positive correlation of shear force and total collagen was found in the medium (III) marbling class, and the correlation proved to be significant only in class II and III. In turn, the correlation between shear force and soluble collagen content was negative in each marbling class. The highest correlation coefficient value was found in IV class $(-0.897)$ and the lowest in class V $(-0.377)$ and only in this class was the relationship not significant.

The correlation between colour $L$ parameter and age at slaughter presented in Table 4 indicates that the relationships in all marbling classes were negative, low and not significant. 
Table 3. Coefficients of Pearson's correlation of shear force with fat and collagen content.

\begin{tabular}{|c|c|c|c|c|}
\hline & \multicolumn{4}{|c|}{ Marbling class } \\
\hline & $\begin{array}{l}\text { II } \\
(n=16)\end{array}$ & $\begin{array}{l}\text { III } \\
(n=16)\end{array}$ & $\begin{array}{l}\text { IV } \\
(n=19)\end{array}$ & $\begin{array}{l}\mathrm{V} \\
(n=17)\end{array}$ \\
\hline & \multicolumn{4}{|c|}{ Shear force $\left(\mathrm{N} \mathrm{cm}^{-2}\right)$} \\
\hline MLL fat (\%) & $-0.636^{*}$ & $-0.897^{*}$ & $-0.643^{*}$ & $-0.753^{*}$ \\
\hline total $\left(\mathrm{mg} \mathrm{g}^{-1}\right)$ & $0.438 *$ & $0.474 *$ & 0.241 & 0.248 \\
\hline soluble ( $\%$ of total collagen) & $-0.490 *$ & $-0.703^{*}$ & $-0.897^{*}$ & -0.377 \\
\hline
\end{tabular}

MLL - musculus longissimus lumborum

* $P<0.05$

Table 4. Coefficients of Pearson's correlation of colour L with slaughter and carcass traits.

\begin{tabular}{lrrrr}
\hline & \multicolumn{4}{c}{ Marbling class } \\
\cline { 2 - 5 } & II & III & IV & V \\
& \multicolumn{5}{c}{ Colour $L$} \\
\cline { 2 - 5 } & $(n=16)$ & $(n=16)$ & $(n=19)$ & $(n=17)$ \\
\hline Age at slaughter (days) & -0.324 & -0.321 & -0.159 & -0.208 \\
Carcass weight (kg) & 0.011 & 0.163 & 0.347 & 0.365 \\
MLL fat (\%) & $0.400^{*}$ & $0.439^{*}$ & $0.424^{*}$ & $0.603^{*}$ \\
\hline
\end{tabular}

MLL - musculus longissimus lumborum

* $P<0.05$

The correlation was also not significant between meat lightness and carcass weight. The relationships in each marbling class were positive and low. The results of meat lightness and MLL fat correlation showed that it was positive and significant in each marbling class. The highest value of the correlation coefficient $(0.603)$ was estimated in the strong $(\mathrm{V})$ class.

\section{Discussion}

It is well known that animal age is one of the factors determining the IMF content (Bruns et al., 2005; Młynek et al., 2006; Webb and O'Neill, 2008; Smith et al., 2009; Węglarz, 2010c). In the present experiment, marbling class affected neither age at slaughter nor carcass weight. In turn, carcass dressing percentage, subcutaneous fat amount, fat of valuable cuts and MLL area varied depending on the content of intramuscular fat. According to May et al. (1992), marbling is closely linked to fat thickness and the percentage of kidney, pelvic and heart fat. The relationships found by these authors were very strong and correlation coefficients ranged from 0.92 to 0.96 . The least significant MLL area despite the highest dressing percentage presented in this study in small marbled muscles (Table 1) may be explained by the very low MLL fat content in II marbling class (Table 2).

Numerous studies performed on various cattle breeds and disparate muscles reported a negative correlation between muscle moisture and fat content (Savell et al., 1986; Kim and Lee, 2003; Ueda et al., 2007). The reason for this is the replacement of moisture with fat when fat content in muscle increases. In the study of Jo et al. (2013), the group of animals with low IMF in longissimus dorsi muscles (average IMF $10.71 \%$ ) had $67.69 \%$ moisture content, while the group with high IMF $(21.07 \%)$ had only $58.45 \%$. Increasing dry matter with increasing marbling in our study is equivalent to decreasing moisture percentage with increasing fat content in the experiments mentioned before. In keeping with our observations, Savell et al. (1986) and Kim and Lee (2003) found a relatively constant level of protein regardless of fat content in bovine muscle. In contrast, Ueda et al. (2007) noted an inexplicable, significant decrease of protein content in higher marbling (up to $39 \%$ of intramuscular fat content) longissimus thoracis muscle of Japanese Black steers. Albrecht et al. (2011) explain that in highly marbled muscle, fat cells replace muscle fibres and reduce protein content in muscle.

The connective tissue is present in all muscles in the epimysium, perimysium and endomysium components encircling muscle fibres. Intramuscular fat located between muscle fibre bundles interrupted the endomysium structure, thus separating and diluting perimysial collagen fibres and disrupting the structure of intramuscular connective tissue (Hocquette et al., 2010). In accordance with Nishimura et al. (1999), this process results in an increase of meat tenderness but only in strongly marbled muscles that contain no less than $8 \%$ of fat. In our study, we found increased meat tenderness expressed as decreased shear force value of MLL in marbling class IV and V compared with II and III (the content of fat was 3.5 and $4.3 \%$, respectively). The values of total collagen content were very similar; however, the percentage of soluble collagen of middle (III), large (IV) and strong (V) marbled longissimus lumborum muscle was significantly reduced as compared to marbling class II. With respect to meat colour, our results do not concur either with Fiems et al. (2000) or with Kim and Lee (2003). The former authors noted that a large amount of intramuscular fat can increase meat lightness, while the latter researchers reported that marbling did not affect the meat colour. 
The significant negative correlations observed in this study between the shear force value (SF) and MLL fat content are in agreement with the results of Ueda et al. (2007), who found a significant negative correlation between SF and fat level of longissimus thoracis muscle from Japanese Black steers. Conversely, some authors observed that the shear force parameter showed no significant relationship with beef fat content or marbling score (Brooks et al., 2000; Jo et al., 2013). The correlation of the collagen and shear force value or sensory tenderness has been observed in several earlier experiments but the results differ. Nakamura et al. (2010) found a positive correlation between shear force and collagen content of the longissimus thoracis muscle of Japanese Black and Brown steers. Collagen characteristics were noticed as a poor indicator of meat toughness from young bulls of fifteen European breeds in the study by Christensen et al. (2011). In turn, in agreement with our results, Chambaz et al. (2003) observed a negative relationship between collagen solubility and tenderness in longissimus dorsi muscle of Charolais steers.

Meat lightness can be determined by several pre- or postslaughter factors and is often inversely correlated with level of haem iron content in muscle myoglobin which increases with animal age (Chambaz et al., 2003). Bureš and Bartoň (2012) have demonstrated that lightness of musculus longissimus lumborum was affected by the interaction between sex and slaughter age of animals, and the meat became darker with increasing age only in heifers but not in bulls. Also in muscles of male Chianina cattle, the different age of slaughter did not influence colour $L$ parameter (Preziuso and Russo, 2004). In contrast, the beef colour stability of musculus psoas, m. major, m. semitendinosus and $m$. longissimus thoracis from Japanese Black steers decreased with age (Muramoto et al., 2003). The suitable age at slaughter and the associated pre-slaughter weight of animals translates into carcass weight and meat quality (Bruns et al., 2004; Węglarz, 2010b). Węglarz (2010b) showed no correlation (0.01) between hot carcass weight and beef lightness of meat from young bulls. The same value was observed in the present study but only in heifers of class II. In another experiment, the same author (Węglarz, 2011) reported no relationship (coefficient of correlation $=0.00$ ) between body weight and colour $L$ trait of individual or group-housed cattle classified according to the EUROP system in four categories. Fiems et al. (2000) reported the negative correlation between colour $L$ values and the fat characteristics in double-muscled and non-double-muscled Belgian Blue bulls.

The results of this study show that marbling significantly affected the dressing percentage and carcass traits such as subcutaneous fat content, fat of valuable cuts and MLL area. Most of the physico-chemical properties of heifer musculus longissimus lumborum, with the exception of total protein and total collagen content, were related to the level of marbling. It can be concluded that age at slaughter and carcass weight are not good predictors of colour lightness of
MLL within all marbling categories. The same conclusion applies to the amount of total collagen in large and strong marbled muscles for shear force value. In turn, soluble collagen content for shear force seems to be a quite good forecaster of meat tenderness but not in strong marbled muscles. Of all tested slaughter and carcass traits, only MLL fat content seems to be appropriate to assess both the tenderness and lightness of meat.

Edited by: S. Maak

Reviewed by: three anonymous referees

\section{References}

Albrecht, E., Gotoh, T., Ebara, F., Xu, J. X., Viergutz, T., Nürnberg, G., Maak, S., and Wegner, J.: Cellular conditions for intramuscular fat deposition in Japanese Black and Holstein steers, Meat Sci., 89, 13-20, 2011.

AOAC: Official methods of analysis. 16th ed., Association of Official Analytical Chemists, Arlington, VA, USA, 1995.

Brooks, J. C., Belew, J. B., Griffin, D. B., Gwartney, B. L., Hale, D. S., Henning, W. R., Johnson, D. D., Morgan, J. B., Parrish, F. C., Reagan, J. O., and Savell, J. W.: National Beef Tenderness Survey-1998, J. Anim. Sci., 78, 1852-1860, 2000.

Bruns, K. W., Pritchard, R. H., and Boggs, D. L.: The relationship among body weight, body composition, and intramuscular fat content in steers, J. Anim. Sci., 82, 1315-1322, 2004.

Bruns, K. W., Pritchard, R. H., and Boggs, D. L.: The effect of stage of growth and implant exposure on performance and carcass composition in steers, J. Anim. Sci., 83, 108-116, 2005.

Bureš, D. and Bartoň, L.: Growth performance, carcass traits and meat quality of bulls and heifers slaughtered at different ages, Czech J. Anim. Sci., 57, 34-43, 2012.

Chambaz, A., Morel, I., Scheeder, M. R. L., Kreuzer, M., and Dufey, P. A.: Characteristics of steers of six beef breeds fattened from eight months of age and slaughtered at a target level of intramuscular fat. I. Growth performance and carcass quality, Arch. Tierz., 44, 395-411, 2001.

Chambaz, A., Scheeder, M. R. L., Kreuzer, M., and Dufey, P. A.: Meat quality of Angus, Simmental, Charolais and Limousin steers compared at the same intramuscular fat content, Meat Sci., 63, 491-500, 2003.

Christensen, M., Ertbjerg, P., Failla, S., Sañudo, C., Richardson, R. I., Nute, G. R., Olleta, J. L., Panea, B., Alberti, P., Juárez, M., Hocquette, J. F., and Williams, J. L.: Relationship between collagen characteristics, lipid content and raw and cooked texture of meat from young bulls of fifteen European breeds, Meat Sci., 87, 61-65, 2011.

Fiems, L. O., De Campeneere, S., De Smet, D., Van de Voorde, G., Vanacker, J. M., and Boucqué, C. V.: Relationship between fat depots in carcasses of beef bulls and effect on meat colour and tenderness, Meat Sci., 56, 41-47, 2000.

Hocquette, J. F., Gondret, F., Baéza, E., Médale, F., Jurie, C., and Pethick, D. W.: Intramuscular fat content in meat-producing animals: development, genetic and nutritional control, and identification of putative markers, Animal, 4, 303-319, 2010.

ISO: International Standard ISO 3496:1994. Meat and meat products - Determination of hydroxyproline content. 2nd ed., Inter- 
national Organization for Standarization, Genéve, Switzerland, 1994.

Jo, C., Jayasena, D. D., Lim, D. G., Lee, K. H., Kim, J. J., Cha, J. S., and Nam, K. C.: Effect of intramuscular fat content on the meat quality and antioxidative dipeptides of Hanwoo beef, Korean J. Food Nutr., 26, 117-124, 2013.

Kim, C. J. and Lee, E. S.: Effects of quality grade on the chemical, physical and sensory characteristics of Hanwoo (Korean native cattle) beef, Meat Sci., 63, 397-405, 2003.

May, S. G., Dolezal, H. G., Gill, D. R., Ray, F. K., and Buchanan, D. S.: Effects of days fed, carcass grade traits, and subcutaneous fat removal on postmortem muscle characteristics and beef palatability, J. Anim. Sci., 70, 444-453, 1992.

Młynek, K., Elminowska-Wenda, G., and Guliński, P.: The relationship between microstructure of Longissimus lumborum muscle and carcass quality of bulls slaughtered at three ages, Anim. Sci. Pap. Rep., 24, 57-63, 2006.

Muramoto, T., Shibata, M., and Nakanishi, N.: Effect of Slaughter Age on Beef Color Stability during Display of Four Muscles from Japanese Black Steer, Asian-Aust, J. Anim. Sci., 16, 13641368, 2003.

Nakamura, Y. N., Tsuneishi, E., Kamiya, M., and Yamada, A.: Histological Contribution of Collagen Architecture to Beef Toughness, J. Food Sci., 75, 73-77, 2010.

Nishimura, T., Hattori, A., and Takahashi, K.: Structural changes in intramuscular connective tissue during the fattening of Japanese Black cattle: effect of marbling on beef tenderization, J. Anim. Sci., 77, 93-104, 1999.

Okumura, T., Saito, K., Nade, T., Misumi, S., Masuda, Y., Sakuma, H., Nakayama, S., Fujita, K., and Kawamura, T.: Effect of intramuscular fat on the sensory characteristics of M. longissimus dorsi in Japanese Black steers as judged by a trained analytical panal, Asian-Aust J. Anim. Sci., 20, 577-581, 2007.

Platter, W. J., Tatum, J. D., Belk, K. E., Koontz, S. R., Chapman, P. L., and Smith, G. C.: Effect of marbling and shear force on consumers' willingness to pay for beef strip loin steaks, J. Anim. Sci., 83, 890-899, 2005.

Preziuso, G. and Russo, C.: Meat quality traits of longissimus thoracis, semitendinosus and triceps brachii muscles from Chianina beef cattle slaughtered at two different ages, Ital. J. Anim. Sci., 3, 267-273, 2004.

Rhee, M. S., Wheeler, T. L., Shackelford, S. D., and Koohmaraie, M.: Variation in palatability and biochemical traits within and among eleven beef muscles, J. Anim. Sci., 82, 534-550, 2004.

Savell, J. W., Cross, H. R., and Smith, G. C.: Percentage Ether Extractable Fat and Moisture Content of Beef Longissimus Muscle as Related to USDA Marbling Score, J. Food Sci., 51, 838-839, 1986.
Searls, G. A., Maddock, R. J., and Wulf, D. M.: Intramuscular tenderness variation within four muscles of the beef chuck, J. Anim. Sci., 83, 2835-2842, 2005.

Smith, S. B., Gill, C. A., Lunt, D. K., and Brooks, M. A.: Regulation of fat and fatty acid composition in beef cattle, Asian-Aust J. Anim. Sci., 22, 1225-1233, 2009.

Šurbt, J., Filipčík, R., Župka, Z., Fialová, M., and Dračková, E.: The content of polyunsaturated fatty acids in intramuscular fat of beef cattle in different breeds and crossbreeds, Arch. Tierz., 49, 340-350, 2006.

Thompson, J. M.: The effects of marbling on flavour and juiciness scores of cooked beef, after adjusting to a constant tenderness, Aust J. Exp. Agric., 44, 645-652, 2004.

Ueda, Y., Watanabe, A., Higuchi, M., Shingu, H., Kushibiki, S., and Shinoda, M.: Effects of intramuscular fat deposition on the beef traits of Japanese Black steers (Wagyu), Anim. Sci. J., 78, 189194, 2007.

Vestergaard, M., Oksbjerg, N., and Henckel, P.: Influence of feeding intensity, grazing and finishing feeding on muscle fibre characteristics and meat colour of semitendinosus, longissimus dorsi and supraspinatus muscles of young bulls, Meat Sci., 54, 177-185, 2000.

Warner, R. D., Greenwood, P. L., Pethick, D. W., and Ferguson, D. M.: Genetic and environmental effects on meat quality, Meat Sci., 86, 171-183, 2010.

Webb, E. C. and O'Neill, H. A.: The animal fat paradox and meat quality, Meat Sci., 80, 28-36, 2008.

Wegner, J., Albrecht, E., Fiedler, I., Teuscher, F., Papstein, H. J., and Ender, K.: Growth- and breed-related changes of muscle fiber characteristics in cattle, J. Anim. Sci., 78, 1485-1496, 2000.

Wulf, D. M., Morgan, J. B., Tatum, J. D., and Smith, G. C.: Effects of animal age, marbling score, calpastatin activity, subprimal cut, calcium injection, and degree of doneness on the palatability of steaks from limousin steers, J. Anim. Sci., 74, 569-576, 1996.

Węglarz, A.: Quality of beef from semi-intensively fattened heifers and bulls, Anim. Sci. Pap. Rep., 28, 207-218, 2010a.

Węglarz, A.: Meat quality defined based on $\mathrm{pH}$ and colour depending on cattle category and slaughter season, Czech J. Anim. Sci., 55, 548-556, 2010b.

Wegglarz, A.: Quality of beef from Polish Holstein-Friesian bulls as related to weight at slaughter, Ann. Anim. Sci., 4, 467-476, 2010c.

Węglarz, A.: Effect of pre-slaughter housing of different cattle categories on beef quality, Anim. Sci. Pap. Rep., 29, 43-52, 2011. 